\title{
A novel poly (L-lactide) degrading thermophilic actinomycetes, Actinomadura keratinilytica strain T16-1 and pla sequencing
}

\author{
Sukhumaporn Sukkhum ${ }^{1,5}$, Shinji Tokuyama ${ }^{2}$, Prachumporn Kongsaeree $^{3}$, \\ Tomohiko Tamura ${ }^{4}$, Yuumi Ishida ${ }^{4}$ and Vichien Kitpreechavanich ${ }^{1,6 *}$ \\ ${ }^{1}$ Department of Microbiology, Faculty of Science, Kasetsart University, Bangkok 10900, Thailand. \\ ${ }^{2}$ Department of Biological chemistry, Faculty of Agriculture, Shizuoka University, Shizuoka 422-8529, Japan. \\ ${ }^{3}$ Department of Biochemistry, Faculty of Science, Kasetsart University, Bangkok 10900, Thailand. \\ ${ }^{4}$ Biological Resource Center (NBRC), Department of Biotechnology, National Institute of Technology and Evaluation, \\ Kisarazu 292-0818, Japan. \\ ${ }^{5}$ Department of Biology, Faculty of Science, Srinakharinwirot University, Bangkok 10110, Thailand. \\ ${ }^{6}$ Center for Advanced Studies in Tropical Natural Resources, Institute for Advanced Studies and Graduated School, \\ Kasetsart University Bangkok 10900, Thailand.
}

\section{Accepted 15 June, 2011}

\begin{abstract}
An actinomycete strain T16-1 demonstrated the maximum poly (L-Lactide)-degrading activity when cultured in basal liquid medium at $50^{\circ} \mathrm{C}$. According to $16 \mathrm{~S}$ rDNA sequence analysis, chemotaxonomic and DNA-DNA hybridization revealed that strain T16-1 belong to the family Thermomonosporaceae, genus Actinomadura. On the basis of phenotypic and phylogenic data, strain T16-1 which is a novel PLA-degrading thermophilic actinomycete was identified as Actinomadura keratinilytica, but the color of its colony on ISP plates, $\mathrm{NaCl}$ tolerant and utilization of mannitol, raffinose and arabinose were different. Partial sequence of poly (L-lactide) depolymerase gene from strain T16-1 was demonstrated. The gene consisting of 222 amino acids was related to serine protease from Streptomyces sp. with 43 to $46 \%$ identity.
\end{abstract}

Key words: Actinomadura keratinilytica, cloning, identification, poly (L-lactide).

\section{INTRODUCTION}

Abundant quantities of plastic wastes are serious problems for global environment and have stimulated the improvement of biodegradable plastics. Poly (L-lactide) (PLA) aliphatic polyester is synthesized from L-lactic acid, which can be produced from farm and agricultural products such as cassava, rice, corn and corncob by fermentation methods (Miura et al., 2004; Wee et al., 2006). Recently, there has been interest in using plastic composting by microbes as a method for treating plastic waste (Tomita et al., 2003).

Several thermophilic bacteria such as Bacillus brevis,

${ }^{\star}$ Corresponding author. E-mail: fsciwck@ku.ac.th. Tel: +662942-8389. Fax: +66-2579-2081.
Bacillus stearothermophilus and Geobacillus thermocatenulatus have been reported to possess PLAdegrading activity (Tomita et al., 1999, 2003, 2004). Some actinomycetes, belonging to members of the family Pseudonocardiaceae were also able to produce enzymes that decompose PLA, such as Amycolatopsis sp., Lenzea waywayandensis and Kibdelosporangium aridum (Jarerat et al., 2002). Recently, PLA-degrading enzyme production by Actinomadura sp. using statistical method was reported by Sukkhum et al. (2009a). Unculturable microorganisms were identified from the compost consisting of PLA by using metagenomic method including Paecilomyces, Thermomonospora and Thermopolyspora (Sangwan and $\mathrm{Wu}, 2008$ ).

In order to screen novel microorganism that are suspected to possess PLA-degrading activity at high 
temperature for composting application and recycling of biodegradable plastic wastes, PLA-degrading actinomycetes were isolated at $50^{\circ} \mathrm{C}$. The strain that produced the highest PLA degrading activity was selected and identified.

This is the first finding of a strain belonging to the species Actinomadura keratinilytica with the capacity to degrade PLA, producing appropriate enzyme at $50^{\circ} \mathrm{C}$. The pla sequencing of a new PLA-degrading strain was investigated in this study.

\section{MATERIALS AND METHODS}

\section{Isolation of PLA-degrading actinomycetes and their enzyme production}

Soil samples $(0.1 \mathrm{~g}$ each) were suspended in $9 \mathrm{ml}$ sterile distilled water mixed well and then plated on an emulsified PLA agar plates. The plates were prepared as follows. $1 \mathrm{~g}$ PLA pellet was dissolved in $40 \mathrm{ml}$ dichloromethane. To $1,000 \mathrm{ml}$ of a basal medium (containing per liter, $\left(\mathrm{NH}_{4}\right)_{2} \mathrm{SO}_{4}, 4 \mathrm{~g} ; \mathrm{K}_{2} \mathrm{HPO}_{4}, 2 \mathrm{~g} ; \mathrm{KH}_{2} \mathrm{PO}_{4}, 1 \mathrm{~g}$; $\mathrm{MgSO}_{4} .7 \mathrm{H}_{2} \mathrm{O}, 0.5 \mathrm{~g}$; yeast extract, $1 \mathrm{~g}$; agar, $15 \mathrm{~g}$, pH 7.0; sterilized at $121^{\circ} \mathrm{C}$ for $\left.15 \mathrm{~min}\right), 40 \mathrm{ml}$ of the PLA solution was added. The medium was sonicated with an ultrasonic processor model VCX 500 (Sonic and Materials, INC., Newtown, USA) for $5 \mathrm{~min}$. The colonies forming clear zones were selected as PLA-degrading strains and were sub-cultured and purified on an emulsified PLA agar plate.

The ability of isolates on the enzyme production was determined in culture broth. The strains were cultured in $250 \mathrm{ml}$ Erlenmeyer flask containing $100 \mathrm{ml}$ of basal liquid medium consisting per liter, PLA film, $1 \mathrm{~g} ;\left(\mathrm{NH}_{4}\right)_{2} \mathrm{SO}_{4}, 4 \mathrm{~g} ; \mathrm{K}_{2} \mathrm{HPO}_{4}, 2 \mathrm{~g} ; \mathrm{KH}_{2} \mathrm{PO}_{4}, 1 \mathrm{~g}$; $\mathrm{MgSO}_{4} .7 \mathrm{H}_{2} \mathrm{O}, 0.5 \mathrm{~g}$; extract, $1 \mathrm{~g}, \mathrm{pH} 7.0$; with shaking speed of 150 rpm for 4 days at $50^{\circ} \mathrm{C}$. The culture broth was centrifuged and the obtained supernatant was used to analyze the PLA-degrading activity. PLA-degrading enzyme activity was assayed based on decrease in turbidity by a modified method of Nakamura et al. (2001) as described by Sukkhum et al. (2009a). One unit of the PLA-degrading activity was defined as a 1 unit decrease in optical density at $630 \mathrm{~nm}$ per min under the assay condition described.

\section{$16 S$ rDNA sequencing and $\mathrm{G}+\mathrm{C}$ content analysis}

For biomass preparation, strain T16-1 was grown in shake flask of tryptone soya broth (TSB) at $50^{\circ} \mathrm{C}$ for 2 to 3 days and harvested by centrifugation. Cells for the chemotaxonomic analysis were washed twice in distilled water and freeze-dried. Cells for the molecular systematic analyses were washed in $\mathrm{NaCl}$-EDTA buffer $(0.1 \mathrm{M}$ EDTA, pH 8.0, $0.1 \mathrm{M} \mathrm{NaCl}$ ) and stored at $-20^{\circ} \mathrm{C}$ until required.

Genomic DNA was extracted from strain T16-1 as described by Hopwood et al. (1985). Further purification steps including RNase treatment were carried out according to the method of Saito and Miura (1963). The $G+C$ content of the DNA was determined by the HPLC method of Tamaoka and Komagata (1984). A gene fragment specific for 16S rRNA gene-coding region was amplified by means of PCR. Two primers, 9F (5'-GAGTTTGATCCTGGCTCAG-3') and 1541R (5'-AAGGAGGTGATCCAGCC-3') were used. All primer positions were specified by the Escherichia coli numbering system (Brosius et al., 1978). The amplified and purified 16S rRNA genes were sequenced directly with a Big Dye terminator V3.1 Cycle sequencing Kit on an $\mathrm{ABI} 3100$ automated DNA sequence (Applied Biosystems, Foster City, Califonia, USA).

Multiple alignments of the sequences obtained were performed using program CLUSTAL X (version 1.81) (Thompson et al., 1997) Gaps and ambiguous bases were eliminated. Comparison of the aligned sequences was made for 1,254 bases of $16 \mathrm{~S}$ rRNA gene sequence in constructing phylogenetic trees by the neighbor-joining method of Saitou and Nei (1987) using the MEGA 3 program (Kumar et al., 2004). Distance matrices for the aligned sequences were calculated by the two-parameter method of Kimura (1980). Robustness for individual branches was estimated by bootstrapping of 1,000 replications (Felsenstein, 1985).

\section{DNA-DNA hybridization}

DNA-DNA hybridization experiments were used to resolve the taxonomic relationships between representatives of these closely related species. Levels of DNA relatedness of strain T16-1 and related organisms was determined with a method modified from that of Ezaki et al. (1989), using the $\beta$-galactosidase/4methylumbelliferyl- $\beta$-galactoside system.

\section{Chemotaxonomic characterization}

The isomer of diaminopimelic acid in the cell wall and the whole-cell sugar pattern were determined as described by Staneck and Roberts (1994). Menaquinones were analysed by LC/MS (Shimadzu LC-MS application data sheet No. 010). Phospholipids were extracted by the method of Minnikin et al. (1979) and identified using two dimensional TLC. Cellular fatty acid methyl esters were prepared and analysed according to the protocol of the MIDI Sherlock Microbial Identification System (Agilent Technologies 6890N Network GC System) (MIDI, 2002; Sasser, 1990).

\section{Cultural and morphological characterization}

To examine the extent of growth, pigmentation and color of colony, strain T16-1 was grown on inorganic salt-starch agar (International Streptomyces Project (ISP-4) as described by Shirling and Gottlieb (1966). Morphological structures were studied using 20 days of strain on humic vitamin agar (HV) and observed by a scanning electron microscope (model JSM6060, JEOL, Ltd., Tokyo, Japan).

\section{Phenotypic characterization}

In addition to PLA degradation, strain T16-1 was also examined for the ability to degrade cellulose (cellulose medium), gelatin (glucosepeptone-gelatin medium), skim milk (skim milk medium) and starch (ISP-4) as described by Hamada (2000), in addition to PLA. NaCl tolerance and growth temperature were assessed using yeast extract-malt extract medium (ISP-2). Utilization of carbon sources was tested by using carbon utilization medium (ISP-9) modified from Pridham and Gottlieb (1948). Each carbon source was added to ISP-9 medium to give a final concentration of $1 \%(\mathrm{w} / \mathrm{v})$. Lactic acid utilization was also tested. The basal medium (Tomita et al., 2003) with $0.1 \%$ lactic acid was used in this test. The results were taken by measuring dry cell weight.

\section{Sequencing of pla from strain T16-1}

\section{Bacterial strains and plasmid}

Strain T16-1 was used as chromosomal DNA sources. Genomic DNA was extracted from strain T16-1 as described by Hopwood et al. (1985). E. coli JM109 was used as the host for recombinant 
plasmid. Plasmid pUC19 was used as vector containing pla.

\section{Preparation of oligonucleotide primers for cloning of pla from strain T16-1}

N-terminal amino acid sequence (NPPSAGLDR) of purified PLAdegrading enzyme was used for design forward primer, plaF (5'CCSWCSGCSGGSCTSGACCG3-'). According to Blast p search, reverse primer was obtained from the most closely related amino acid sequence, plaR (5'-GGSGTSGCCATSGWSGTSCC-3'). In the sequences, $S$ represent $C$ or $G$ and $W$ represent $A$ or $T$. After PCR amplification, a ca. $650 \mathrm{bp}$ fragment was obtained from genomic DNA of strain T16-1 using Takara Ex Taq polymerase.

\section{Cloning of pla and Its DNA sequencing}

Vector (pUC19) was digested by Smal and ligated with pla. The plasmid containing pla was designed as pUCpla. Plasmid pUCpla was introduced into protoplast of $E$. coli JM109, a recombinant $E$. coli strain containing pla was selected by blue/white colony on Luria-Bertani (LB) medium containing $10 \mathrm{mg} / \mathrm{ml}$ ampicillin, IPTG and X-gal. Recombinant plasmid (pUCpla) was extracted according to nucleospin plasmid kit and direct sequence of multiple containing site (MCS) by using two oligonucleotide primers, M13F (5'GTAAAACGACGGCCAG-3') and M13R (5'GGAAACAGCTATGACCATG-3').

Protein and nucleotide sequences were compared with those on databases using FASTA (version 3.0) and BLAST (version 1.49) programs implemented at the EMBL/GenBank/DDBJ nucleotide sequence databases. Multiple-sequence alignment was done using a GENETYX program (Software Development Co., Tokyo, Japan).

\section{RESULTS}

\section{Isolation of PLA-degrading actinomycetes and their PLA degrading activity}

Eighty samples of surface layer soil were taken from Huai kha khaeng wildlife sanctuaries, Uthaithani province, Thailand. However, among these soil samples, only 10 samples were found 11 active strains isolated at $50^{\circ} \mathrm{C}$ and 2 isolates at $40^{\circ} \mathrm{C}$. This indicates that PLA-degrading microorganisms could be regarded as having a lower population in the soil as reported by Pranamuda et al. (1997) and Ikura and Kudo (1999).

Among these, strain T16-1 produced the highest PLAdegrading activity at $22 \mathrm{U} / \mathrm{ml}$, while, strains T16-4 and T9-1 produced 15 and $10 \mathrm{U} / \mathrm{ml}$, respectively. The clear zone formation on emulsified PLA agar and enzyme activity in culture broth did not show a strong correlation, but some strains which had high activity might have a larger clear zone. Beside the size of clear zone, strains T16-1, T16-4, T9-1 and T7-1 demonstrated high clearness on the plate, which could associated with the extent of their activity in culture broth.

The GenBank accession number for the 16S rRNA sequence of strain T16-1 is FJ199994. The strain T16-1 was deposited in culture collection as BCC 28970 and NBRC 104111.

\section{Genotypic properties}

For classification, strain T16-1 was subjected to a polyphasic investigation. In a phylogenetic tree based on 16S rRNA gene sequences for 1,254 nucleotides (nt), strain T16-1 clustered with the members of the genus Actinomadura (Figure 1). The highest levels of $16 \mathrm{~S}$ rRNA gene sequence similarity was found to be Acinomadura keratinilytica WCC-2265 $5^{\top} \quad(100 \%)$, Actinomadura rubrobrunea NBRC $15275^{\top}(98.0 \%)$ and Actinomadura viridilutea NBRC $14480^{\top}(97.9 \%)$.

In the present investigation, it was evident that DNADNA relatedness values in reciprocal hybridizations were much lower than $70 \%$, indicating that bacterial strain represents a separate genomic species. In the case of strain T16-1 and related species: [A. keratinilytica WCC$2265^{\top}(80.1$ to $86.5 \%)$, A. viridilutea NBRC $14480^{\top}(30.3$ to $33.2 \%$ ) and $A$. rubrobrunea NBRC $15275^{\top}$ (34.4$36.6 \%)$, strain $\mathrm{T} 16-1$ should be identified as $A$. keratinilytica. The $\mathrm{G}+\mathrm{C}$ content of the DNA was 72.2 $\mathrm{mol} \%$.

\section{Chemotaxonomic characterization of Strain T16-1}

Strain T16-1 contained meso-diaminopimelic acid. Galactose, glucose, madurose, mannose and ribose were detected in whole-cell hydrolysates indicating a chemotype IIIB cell wall (Lechevalier and Lechevalier, 1970). Polar lipids of strain T16-1 included diphosphatidylglycerol, phosphatidylinositol, phosphatidylglycerol and phosphatidylinositol mannosides. 14-Methyl-pentadecanoic acid (16:0 iso; $23 \%$ of total fatty acids) and 15-methyl-hexadecanoic acid (17:0 iso; $30 \%$ of total fatty acids) were the major fatty acids (Table 1 ).

WCC- $2265^{\top}$ also produced a relatively large proportion of iso-branched fatty acids, predominantly $16: 0$ iso and 17:0 iso. The major menaquinones of strain T16-1 were MK-9 $\left(\mathrm{H}_{6}\right)(61 \%)$, MK-9 $\left(\mathrm{H}_{4}\right)(18 \%)$ and MK-9 $\left(\mathrm{H}_{8}\right)(17 \%)$. In addition, a small amount of MK- $9\left(\mathrm{H}_{2}\right)$ was detected. Fatty acid, DAP type and menaquinones of strain T16-1 was the same as strain WCC-2265 ${ }^{\top}$ (Puhl et al., 2009). The results summarized in Table 1 suggest that strain T16-1 belonged to the genus Actinomadura sp.

\section{Cultural and morphological characteristics}

The phenotypic properties of strain T16-1 and WCC2265 was shown in Table 2. Strain T16-1 exhibited good growth on ISP-2, ISP-3 and ISP-4. The substrate mycelium of the strain T16-1 was cream-yellow. The aerial mycelia were rare but when present green on ISP4. This was different from substrate mycelium of WCC$2265^{\top}$ which was yellow-orange on ISP-2 and gray-white on ISP-3 and ISP-4. Morphological observation of a 20-d- 


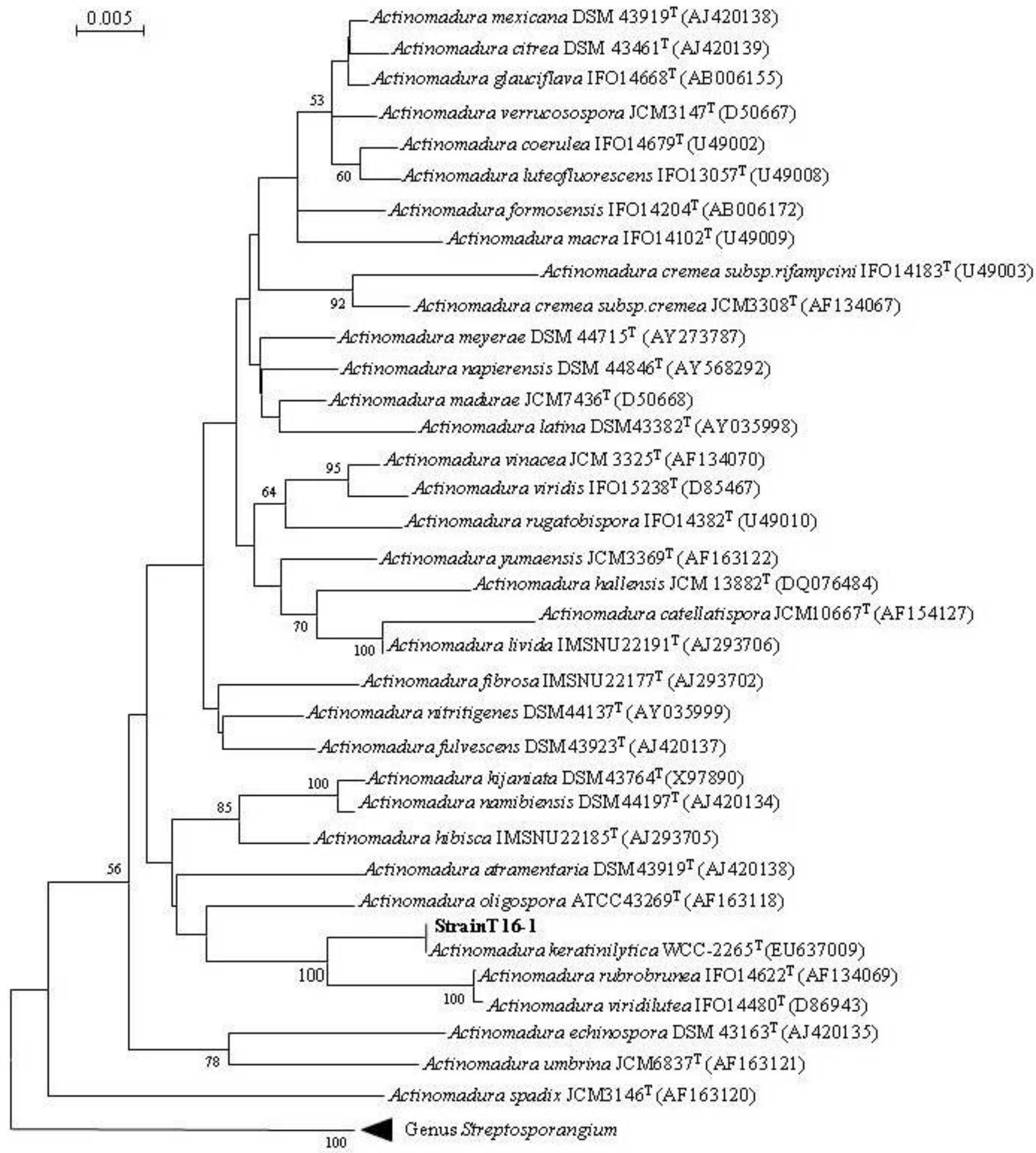

Figure 1. Neighbour-joining tree based on nearly complete 16S rRNA gene sequences showing relationships of strainT16-1 to representatives of validly described species of Actinomadura. Bootstrap values at branching points are expressed as percentages from 1000 replications (only values greater than $50 \%$ are indicated). The scale bar indicates 0.005 substitution per nucleotide position. $\mathrm{T}$, type strain.

old culture of the strain grown on Humic vitamin (HV) agar revealed the presence of oligosporic curved chains of spiny spores.

\section{Phenotypic properties of strain T16-1}

Strain T16-1 utilized D-glucose, inositol, raffinose, 
Table 1. Chemotaxonomic characteristic of strain T16-1.

\begin{tabular}{|c|c|}
\hline Characteristic & Strain T16-1 \\
\hline DAP type & meso-DAP \\
\hline Sugar type & Type IIIB (Galactose, glucose, madurose, mannose and ribose) \\
\hline Phospholipid & $\begin{array}{l}\text { Diphosphatidylglycerol, phosphatidylinositol, phosphatidylglycerol, } \\
\text { phosphatidylinositol mannosides }\end{array}$ \\
\hline \multicolumn{2}{|l|}{ Menaquinone } \\
\hline $\mathrm{MK}-9\left(\mathrm{H}_{6}\right)$ & $61 \%$ \\
\hline $\mathrm{MK}-9\left(\mathrm{H}_{4}\right)$ & $18 \%$ \\
\hline MK-9 $\left(\mathrm{H}_{8}\right)$ & $17 \%$ \\
\hline MK-9 $\left(\mathrm{H}_{2}\right)$ & small amount \\
\hline \multicolumn{2}{|l|}{ Fatty acid ${ }^{*}$} \\
\hline $15: 0$ iso & $14.8 \%$ \\
\hline 15:0 & $6.7 \%$ \\
\hline $16: 0$ iso & $22.8 \%$ \\
\hline $16: 0$ & $7.3 \%$ \\
\hline $17: 0$ iso & $29.6 \%$ \\
\hline 17:0 & $13.6 \%$ \\
\hline 17:0 10 methyl & $5.3 \%$ \\
\hline
\end{tabular}

*Abbreviations for fatty acids: 15:0 iso, 13-methyltetradecanoic acid; 15:0, pentadecanoic acid; 16:0 iso, 14methylpentadecanoic acid; 16:0, hexadecanoic acid; 17:0 iso, 15-methyl hexadecanoic acid; 17:0, heptadecanoic acid; 17:0 10-methyl, 10-methyl heptadecanoic acid.

sucrose, D-fructose, L-rhamnose, D-xylose, L-arabinose, D-mannose and L-lactic acid. Strain T16-1 was positive for cellulose, gelatin, skim milk and PLA degradation, nitrite from nitrate and starch hydrolysis. The temperature range for growth was 30 to $60^{\circ} \mathrm{C}$. Strain T16-1 tolerates $3 \% \mathrm{NaCl}$ in the medium (Table 2). Optimum temperature and $\mathrm{pH}, \mathrm{NaCl}$ tolerant and utilization of mannitol, raffinose and arabinose of strain T16-1 as shown in Table 2 were different from type strain of $A$. keratinilytica WCC$2265^{\top}$ (Puhl et al., 2009)

\section{Cloning and sequencing of pla}

The PCR product of $650 \mathrm{bp}$ was ligated with pUC19/Smal and transformed to E. coli JM109. Blue/white colony selection on LB+ampicillin+X-gal+IPTG plate was performed and white colony was selected as recombinant strain. The recombinant plasmid was extracted from the recombinant strain and cleaved by EcoRl and HindllI. The DNA fragment containing DNA sequences from plasmid pUC19 (vector) was obtained. Recombinant plasmid was extracted from recombinant strain and directly sequence based on the described method.

The DNA sequences of pla was translated to amino acid sequences, alignment (Figure 2) and blast searched for the most closely related gene from DDBJ/GenBank/EMBL amino acid sequence databases.
The pla (222 amino acids) from A. keratinilytica T16-1 was the most closely related to Streptomyces griseus subsp. griseus NBRC 13350 putative secreted subtilisinlike serine protease of $43 \%$ identity and alkaline serine protease from Streptomyces pristinaespiralis ATCC 25486 of $46 \%$ identity which is different from the reported pla sequences.

\section{DISCUSSION}

The clear zone method is easy and significantly enhanced the isolation of PLA-degrading microorganisms from the environment. Amycolatopsis sp. strain HT-32 and strain K104-1 were isolated from soil samples by using plate count and clear zone method on an emulsified PLA agar plate for at least 14 days at $30^{\circ} \mathrm{C}$ (Pranamuda et al., 1997). In this work, clear zone formation was observed from the isolate T16-1 within 7 days on the plate at $50^{\circ} \mathrm{C}$, indicating that the strain produced PLA-degrading enzyme at higher temperature. The maximum enzyme activity, $44.0 \mathrm{U} / \mathrm{ml}$ was obtained by using response surface methodology after 4 days cultivation in shake flask and $150 \mathrm{U} / \mathrm{ml}$ in an airlift fermenter at $0.5 \mathrm{vvm}$, initial $\mathrm{pH} 7.0$ and $50^{\circ} \mathrm{C}$ (Sukkhum et al., 2009a).

In previous studies, several strains of Amycolatopsis sp. were reported as potent strains in their ability of PLA 
Table 2. Comparison of phenotypic properties of strain T16-1 and WCC-2265 ${ }^{\top}$.

\begin{tabular}{|c|c|c|}
\hline Characteristic & T16-1 & ${ }^{*}$ WCC-2265 ${ }^{\top}$ \\
\hline meso- DAP type & + & + \\
\hline \multicolumn{3}{|l|}{ Conidia } \\
\hline Chain arrangement & Flexous & Flexous-straight \\
\hline Number in chains & 10 & $5-15$ \\
\hline Shape/ornamentation & Globose/spiny & Globose/aculeate \\
\hline \multicolumn{3}{|l|}{ Color of colony } \\
\hline ISP-2 & Cream-yellow & Yellow-orange \\
\hline ISP-3 & Cream & Gray-white \\
\hline ISP-4 & Cream-yellow & Gray-white \\
\hline \multicolumn{3}{|l|}{ Aerial hyphae } \\
\hline ISP-2 & Green-white & Trace \\
\hline ISP-3 & White & - \\
\hline ISP-4 & Greenish gray & - \\
\hline \multicolumn{3}{|l|}{ Growth at/in } \\
\hline Temperature & $30-60^{\circ} \mathrm{C}$, optimum at $50^{\circ} \mathrm{C}$ & $30-55^{\circ} \mathrm{C}$, optimum at $45^{\circ} \mathrm{C}$ \\
\hline $\mathrm{NaCl}$ conc. & & $>6 \% \mathrm{NaCl}$ \\
\hline $\mathrm{pH}$ & $\mathrm{pH} 6-8$, optimum at $\mathrm{pH} 7$ & $\mathrm{pH} 4-10$, optimum at $\mathrm{pH} 6-9$ \\
\hline \multicolumn{3}{|l|}{ Utilization of } \\
\hline Arabinose & + & $+/-$ \\
\hline Fructose & + & + \\
\hline Glucose & + & + \\
\hline Inositol & + & + \\
\hline Mannitol & + & - \\
\hline Raffinose & + & - \\
\hline Rhamnose & + & + \\
\hline Sucrose & + & + \\
\hline Xylose & + & + \\
\hline
\end{tabular}

+, positive or present; -, negative or absent; +/-, not positive but not negative. *Puhl et al. (2009).

degradation (Pranamuda et al., 1997; Pranamuda et al., 2001; Tokiwa and Jarerat, 2004). Furthermore, other actinomycete strains such as $L$. waywayandensis and $K$. aridum also exhibited PLA degrading activity (Jarerat et al., 2004). Un-cultural strain such as Paecilomyces, Thermomonospora and Thermopolyspora were found to be predominant strains in compost that consist of PLA (Sangwan and $\mathrm{Wu}, 2008$ ). Phenotypic and genetic data obtained from strain T16-1 lead to its identification as $A$. keratinilytica, which is a novel PLA-degrading thermophilic actinomycete strain.

Although, 16S rDNA sequencing and DNA-DNA hybridization indicated that strain T16-1 was the same as type strain (WCC-2265 ${ }^{\top}$ ), some phenotypic characterizations, such as color of colony on ISP plates, optimum temperature and $\mathrm{pH}, \mathrm{NaCl}$ tolerance and utilization of mannitol, raffinose and arabinose were different.
The gene sequencing demonstrated that pla is related to serine protease secreted from Streptomyces griseus subsp. griseus. This result correlates with the N-terminal of the purified enzyme which showed the similarity with serine protease from Streptomyces avermitilis MA-4680 as described by Sukkhum et al. (2009b).

\section{ACKNOWLEDGMENTS}

The scholarship from the Royal Golden Jubilee Ph.D. Program is gratefully acknowledged. This work was carried out under the collaboration of the Core University Program among Yamaguchi University, Khonkaen University and Kasetsart University, supported by the International Cooperation Project "Thai-Japan Academic Cooperation Project with the support of the NRCT and 


\begin{tabular}{|c|c|c|}
\hline S.griseus & AKVVQNKKFSIDATQDNPPSWGLDRTDQTETAGDNAYTYPDAGGE--GVIIAYVIDTGVRV & 58 \\
\hline S.pristina & AKVVQNKKFTINATQDNPPSWGLDRVDQADTAGDSKYNYPDSAGE--GVIAYVIDTGVRI & 58 \\
\hline S.avermiti & ASVAQDTEVALDHYQKNPPSWGLDRIDQNDLPLDHGYTWPESSGAGAGVITYVIDTGIRV & 60 \\
\hline PIa gene & 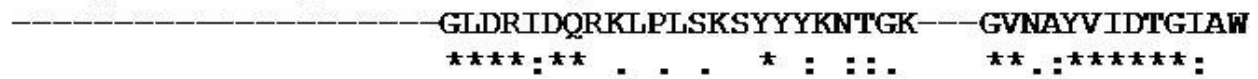 & 36 \\
\hline S.griseus & THEDEEGRATSGEDAVDNDDDADDGNGHGTHVAGTIAGAAHGVAKKANIVAVRVLDDNGS & 8 \\
\hline S.pristina & SHKDFEGRATHGEDAVDNDDSADDGNGHGTHVAGT IAGAAHGVAKKAKIVAVRVLDDNGS & 8 \\
\hline S. avermiti & THRDFGGRASYGWDFVDGDRTAGDGNGHGTHVAGTIAGTTYGVAKQAKVVAVRVLDNEGS & 120 \\
\hline PIa gene & 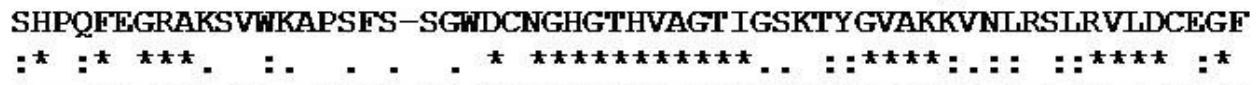 & 95 \\
\hline S.griseus & GTIEQVIAGWWVIENASGPSVANMSLGGGADPALDAAVQKATAAGITFGVAAGNESSDA & \\
\hline S.pristina & GITEQVVAGWWVTQNHQGPSVANMSLGGGADEALDEAVRKATAAGVTFGVAAGNESSDA & 8 \\
\hline S.avermiti & GTIARVIAGWWVTRHAKKPAVANLSLGGEANAQLDAAVRNSIASGVTYAVAAGNDGIAA & 180 \\
\hline pla gene & 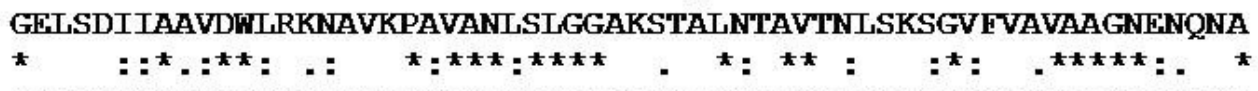 & 5 \\
\hline S.griseus & GEGSPSRVPEATTVASSTEADEQSSESNYGPVVDIYAPGSDITSTWNDSDSGTNTISGTS & \\
\hline S.pristina & AQGSPSRVKEATTVASSTKEDAQSDFSNFGEIVDIYAPGSDITSSWNDSDEGTKTISGTS & 238 \\
\hline S. avermiti & GLYSPAHVKQATTVGAGDRKDARASESNWGPRLDLEAPGVAITSASNASDTAKATFSGTS & 240 \\
\hline PIa gene & 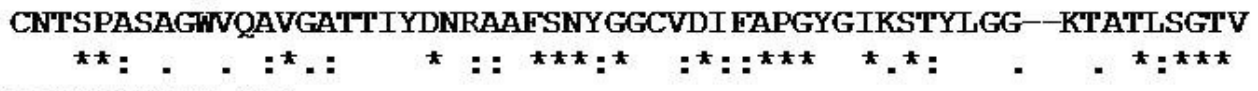 & 213 \\
\hline$S . G$ & MATPHVVGAA 248 & \\
\hline stina & MATPHVVGAA 248 & \\
\hline miti & MATPHVTGAA 250 & \\
\hline pla & QARDGGTEI- 222 & \\
\hline
\end{tabular}

Figure 2. Alignment of pla with the most closely related amino acid sequences of serine protease.

JSPS, Asian Core Program. A part of this research was funded by Center for Advanced Studies in Tropical Natural Resources, Institute for Advanced Studies and Graduated School, Kasetsart University.

\section{REFERENCES}

Brosius J, Palmer ML, Kennedy PJ, Noller HF (1978). Complete Nucleotide Sequence of a 16S Ribosomal RNA Gene from Escherichia coli. Proc. Natl. Acad. Sci. USA., 75: 4801-4805.

Ezaki T, Hashimoto Y, Yabuuchi E (1989). Fluorometric deoxyribonucleic acid-deoxyribonucleic acid hybridization in microdilution wells as an alternative to membrane filter hybridization in which radioisotopes are used to determine genetic relatedness among bacterial strains. Int. J. Syst. Bacteriol., 39: 224-229.

Felsenstein J (1985). Confidence limits on phylogenies: An approach using the bootstrap. Evolution, 39: 783-791.

Hamada M (2000). Cultural and biochemical properties, In Miyadoh S (ed) Identification Manual of Actinomycetes, Business Center for Academic Societies Japan, Tokyo, pp. 37-47

Hopwood DA, Bibb MJ, Chater KF, Kieser T, Bruton CJ, Kieser HM, Lydiate DJ, Smith CP, Ward JM, Schrempf H (1985). Preparation of chromosomal, plasmid and phage DNA, In Crowe F, Sons (eds) Genetic Manipulation of Streptomyces A Laboratory manual, Norwich, pp. 79-80

Ikura Y, Kudo $T$ (1999). Isolation of a microorganism capable of degrading poly(L-lactide). J. Gen. Appl. Microbiol., 45: 247-251.

Jarerat A, Pranamuda H, Tokiwa Y (2002). Poly(L-lactide)-degrading activity in various actinomycetes. Macromol. Biosci., 2: 420-428.

Jarerat A, Tokiwa Y, Tanaka H (2004). Microbial poly(L-lactdie)degrading enzyme induced by amino acids, peptides, and poly(Lamino acids). J. Polym. Eviron., 12(3): 139-146.

Kimura M (1980). A simple method for estimating evolutionary rates of base substitutions through comparative studies of nucleotide sequences. J. Mol. Evol., 16: 111-120.

Kumar S, Tamura K, Nei M (2004). MEGA3: Integrated software for molecular evolutionary genetics analysis and sequence alignment. Brief Bioinform., 5(2): 150-163.

Lechevalier MP, Lechevalier HA (1970). Chemical composition as a criterion in the classification of aerobic actinomycetes. Int. J. Syst. Bacteriol., 20: 435-443.

MIDI (2002). MIS operating manual, version 4.5. MIDI, Inc., Newark, Delaware.

Minnikin DE, Collins MD, Goodfellow M (1979). Fatty acid and polar lipid composition in the classification of Cellulomonas, Oerskovia and related taxa. J. Appl. Bacteriol., 47: 87-95.

Miura S, Arimura T, Itoda N, Dwiarti L, Feng JB, Bin $\mathrm{CH}$, Okabe $\mathrm{M}$ (2004). Production of L-Lactic acid from corncob. J. Biosci. Bioeng., 97(3): 153-157.

Nakamura K, Tomita T, Abe N, Kamio $Y$ (2001). Purification and characterization of an extracellular poly(L-lactic acid) depolymerase from a soil isolate, Amycolatopsis sp. strain K104-1. Appl. Environ. Microbiol., 67: 345-353.

Pranamuda H, Tokiwa Y, Tanaka H (1997). Polylactide degradation by an Amycolatopsis sp. Appl. Environ. Microbiol., 63:1637-1640.

Pranamuda H, Tsuchii A, Tokiwa Y (2001). Poly (L-lactide)-degrading enzyme produced by Amycolatopsis sp. Macromol. Biosci., 1: 25-29.

Pridham TG, Gottlieb D (1948). The utilization of carbon compounds by some Actinomycetales as an aid for species determination. J. Bacteriol., 56: 107-114.

Puhl AA, Selinger LB, McAllister1 TA, Inglis GD (2009). Actinomadura keratinilytica sp. nov., a keratin-degrading actinobacterium isolated from bovine manure compost. Int. J. Syst. Evol. Microbiol., 59: 828834.

Saito H, Miura K (1963). Preparation of transforming deoxyribonucleic acid by phenol treatment. Biochim. Biophys. Acta., 72: 619-629.

Saitou N, Nei M (1987). The neighbor-joining method: A new method for reconstructing phylogenetic trees. Mol. Biol. Evol., 4: 406-425. 
Sangwan P, Wu DY (2008). New insight into polylactide biodegradation from molecular ecological techniques. Macromol. Biosci., 8: 304-315.

Sasser M (1990) Identification of bacteria by gas chromatography of cellular fatty acids. Microbial ID, Inc., Newark, Delaware.

Shimadzu LC-MS application data sheet No. 010. Analysis of menaquinones produced by actinomycetes using LC-MS. Source: http://www.shimadzu.com.br/

analitica/aplicacoes/cromatografos/lc_ms/lcms022.pdf, March 1, 2010.

Shirling EB, Gottlieb D (1966). Methods for characterization of Streptomyces species., Int. J. Syst. Bacteriol., 16: 317-327.

Staneck JL, Roberts GD (1994). Simplified approach to identification of aerobic actinomycetes by thin-layer chromatography. Appl. Microbiol., 28(2): 226-231.

Sukkhum S, Tokuyama S, Kitpreechavanich V (2009a). Development of fermentation process for PLA-degrading enzyme production by a new thermophilic Actinomadura sp. T16-1. Biotechnol. Bioprocess Eng., 14: 302-306.

Sukkhum S, Tokuyama S, Tamura T, Kitpreechavanich V (2009b). A novel poly(L-lactide) degrading actinomycetes isolated from Thai forest soils,

phylogenic relationship and enzyme characterization. J. Gen. Appl. Microbiol., 55: 459-467.
Tamaoka J, Komagata K (1984). Determination of DNA base composition by reversed- phase high-performance liquid chromatography. FEMS Microbiol Lett., 25: 125-128.

Thompson JD, Gibson TJ, Plewniak F, Jeanmougin F, Higgins DG (1997). The CLUSTAL X windows interface: Flexible strategies for multiple sequence alignment aided by quality analysis tools. Nucl. Acid. Res., 25: 4876-4882.

Tokiwa Y, Jarerat A (2004). Biodegradation of poly(L-lactide). Biotechnol. Lett., 26: 771-777.

Tomita K, Tsuji H, Nakajima T, Kikuchi Y, Ikarashi K, Ikeda N (2003). Degradation of Poly(D-Lactic acid) by a thermophile. Polym. Degrad. Stab., 81: 167-171.

Tomita K, Kuroki Y, Nagai K (1999). Isolation of Thermophiles degrading Poly(L-lactic acid ). J. Biosci. Bioeng., 87: 752-755.

Tomita K, Nakajima T, Kikuchi Y, Miwa N (2004). Degradation of poly(Llactic acid) by a newly isolated thermophile. Polym. Degrad. Stab., 84: 433-438.

Wee YJ, Kim JN, Ryu HW (2006). Biotechnological production of lactic acid and its recent applications. Food Technol. Biotechnol., 44: 163172. 